\title{
Study of The Use of Composite Flour Waste of Bean Sprouts Skin with Ganyong Flour (Canna edulis Kre.) Against The Characteristics of Probiotic Biscuit
}

\author{
Florentina Dwi Putri, ${ }^{*}$, Indira Lanti Kayaputri. ${ }^{1}$, Heni Radiani Arifin ${ }^{1}$ \\ 1Departement of Food-industrial Technology, Faculty of Agro-industrial Technology \\ Universitas Padjadjaran, Jatinangor, Bandung, Indonesia.
}

Email: flrndwputri@gmail.com*

\begin{abstract}
The skin of bean sprouts is a waste in the process of green beans into sprouts, while ganyong is a typical local tuber of west java which is very rarly used. Waste of bean sprouts has high fiber and protein content, while ganyong has high carb content. Both raw materials have potential to be processed into a probiotics biscuit products. Biscuit probiotics is a biscuit that has a probiotic content that is instrumental in human body digestion. This research aims to set the offset of composite waste skin of bean sprouts and ganyong flour with good characteristic and liked by the panelist. Research method are conduct experimental by using random block design continued with Duncan test. The treatment used is a variety of formula waste skin of bean sprouts flour (TLKT) : ganyong flour (TG : flour (TT); (P1) 20\%:60\%:20\%, (P2) 30\%:50\%:20\%, (P3) 40\%:40\%:20\% against the total weight of biscuit probiotics dough. The source of probiotic is obtained from adding freeze dried culture in mother culture form. Probiotic biscuits' organoleptic characteristic were testing through hedonic test by 15 semitrained panelist. Research results shows the difference of those TLKT and TG gives a real different influence against taste, but give not real different against color, aroma, visibility, texture, after taste of probiotic biscuit. Probiotic biscuit formula P2 (30\% TLKT:50\% TG) selected as the best treatment also liked a bit by the panelist.
\end{abstract}

Keywords: freeze dried, ganyong flour, probiotic biscuit, skin waste of bean sprouts flour

\section{INTRODUCTION}

Bean sprouts are considered less useful because it is a waste in the processing of gree $\mathrm{n}$ beans into bean sprouts [1]. The total prod uction of bean sprouts in Bogor area is about 6.5 tons / day and the chance to produce bea n sprouts of 1.5 tons / day. [2] Total national vegetable consumption of bean sprouts is 24 0,340 tons / year. However, in general, bean sprouts are only discarded and not used furt her or only used as animal feed.

In fact, skin sprouts waste itself is know $\mathrm{n}$ to have a water content of $63.35 \%$; ash 7.35 $\%$; fat $1.17 \%$; crude protein $13.63 \%$; TDN (T otal Digestible Nutrient) 64.65\%, especially c rude fiber $49.44 \%$ [1]. Based on the source, $t$ he nutrient content, especially protein and fi ber contained in the waste of bean sprouts ca $\mathrm{n}$ be used to create a practical product that is possible to overcome the problem of balance $\mathrm{d}$ nutrition such as probiotic products.

The use of bean sprouts waste as one of the raw materials of probiotic products is do ne with the aim to increase the value of use a nd economical waste. However, the nutrient content of waste sprouts only show low prot ein content and in the form of non gluten and fiber is high enough. Therefore, it is necessar $y$ combination with other flour which has oth er nutrient content such as carbohydrate eno ugh to combine the nutritional raw material of this probiotic product like ganyong flour. 
Ganyong flour itself is a local flour typica l of West Java but is still rarely used especiall $y$ in food products. [3] The productivity of ga nyong in Java is about 30 tons / ha, while the potential can reach 44.5-49.40 tons / ha (8 m onths old ganyong tubers). However, the use of ganyong is still limited only by boiling, wh ereas ganyong is one of nutritious food, espec ially vitamin $\mathrm{B} 1$, phosphorus, carbohydrate, $\mathrm{c}$ alcium and iron [4]. In fact, [5] ganyong flour has a high nutrient content such as crude fibe $r$ of $5.12 \%-5.24 \%$; and starch by $40.18 \%$.

Based on the above matters, the two raw materials of skin waste of beans sprouts flou $r$ and ganyong flour can be used to make a pr oduct that is practical, easy to consume and much in demand in the form of probiotic bisc uits. Biscuits are dried food products made $b$ y baking dough containing flour, fat, and deve loper ingredients with or without the additio $\mathrm{n}$ of food and allowable food additives [6].

In addition, this probiotic biscuit will be made by the addition of freeze dried culture $c$ onsisting of bacteria L. acidophilus, L. bulgari cus, and $S$. thermophilus. Freeze dried culture is a probiotic bacteria that will utilize nutrien t content to produce lactic acid and acetic aci $\mathrm{d}$ in the intestine and can suppress the growt h of E. coli bacteria [7]. The probiotics will wo rk by inhibiting the growth of pathogenic bac teria in the intestinal mucosa in order to prev ent colonization by pathogenic bacteria [8].

Based on the potency of waste of bean sprouts and ganyong flour which is still untapped, it encourages the authors to examine the effect of the balance between the bean sprouts waste flour and the flour of ganyong on some characteristics of probiotic biscuit which can be accepted and favored by the community through testing the organoleptic properties of biscuit by hedonic test method or joy.

\section{MATERIALS AND METHODS}

Materials used in this research were skin waste of bean sprouts flour, ganyong flour, flour, freeze dried culture, sugar, salt, margarine, full cream milk powder, egg yolk, bakin soda, baking powder.
The method used was a randomized block design with comparing between 3 treatments :

A. Skin waste of bean sprouts flour : ganyong flour : flour (20\% : 60\% : 20\% $(b / b))$

B. Skin waste of bean sprouts flour : ganyong flour : flour (30\% : 50\% : 20\% (b/b))

C. Skin waste of bean sprouts flour : ganyong flour : flour $(40 \%: 40 \%: 20 \%$ $(\mathrm{b} / \mathrm{b}))$

\subsection{Implementation of Research}

\subsubsection{Making of Skin Waste of Bean Sprouts Flour Procedure}

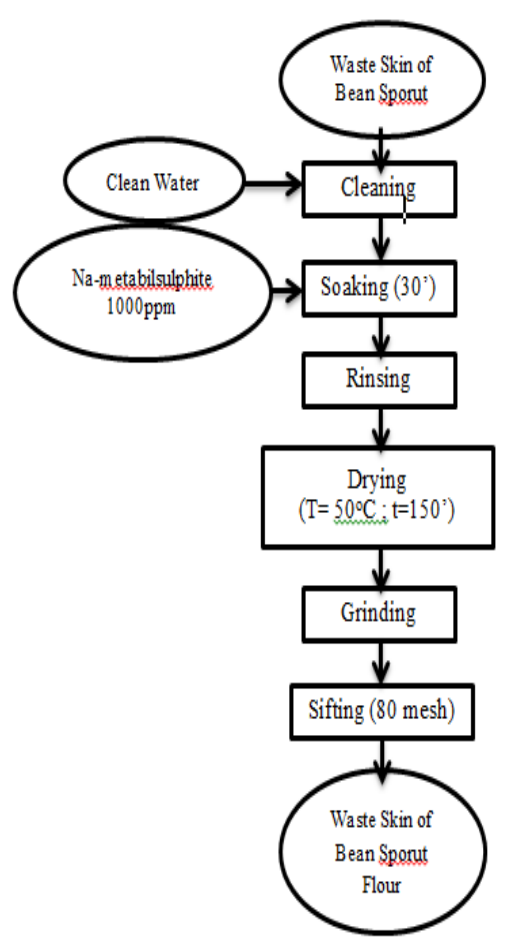

Figure 1. [9] Manufacturing Process of Skin Waste of Bean Sprouts Flour Diagram

\subsubsection{Making of Ganyong Flour Procedure}




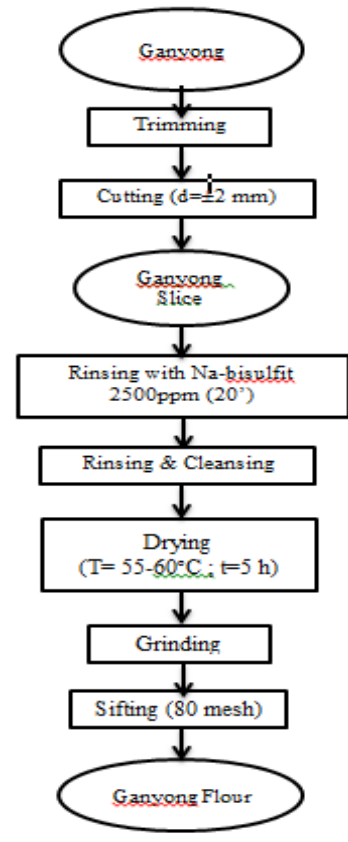

Figure 2. [10] Manufacturing Process of Ganyong Flour Diagram

\subsubsection{Making of Probiotic Biscuit Procedure}

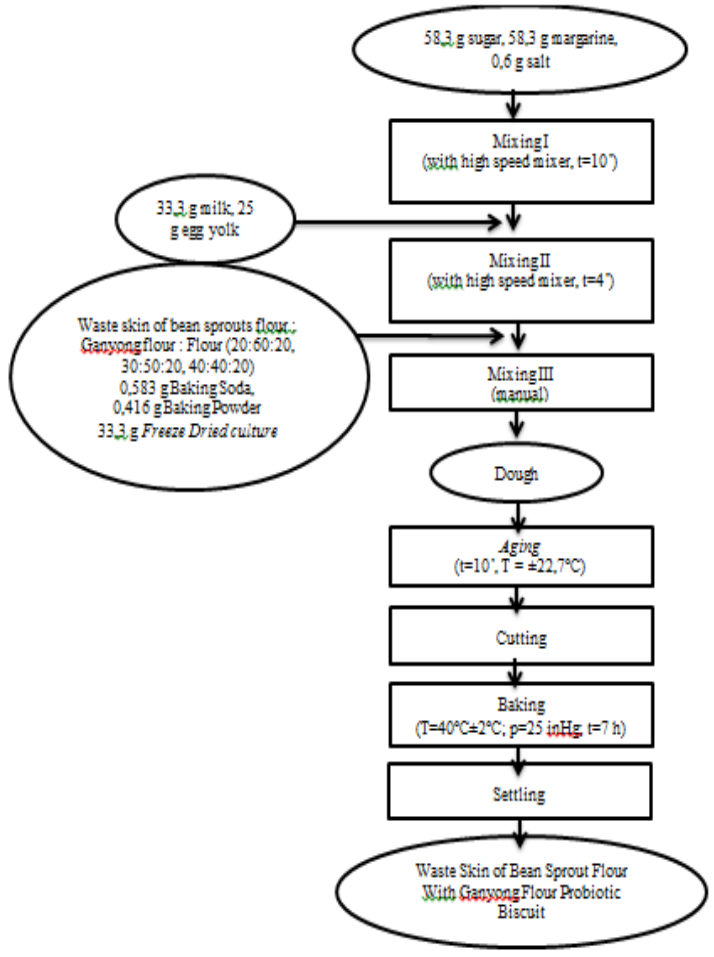

Figure 3. [11] Manufacturing Process of Making of Probiotic Biscuit Diagram

\subsection{Analysis Procedure}

\subsubsection{Biscuit's Organoleptics Characteristics Test by Hedonic Method}

Tests of organoleptic properties were performed [12] with hedonic test or preference on color, aroma, taste, overall appearance, texture, after taste of probiotic biscuits. The assessment was performed using 15 semi-trained panelists using the scoring method (1 to 6), namely: (1) strongly disliked, (2) dislikes, (3) somewhat dislikes, (4) rather likes, (5) likes (6) really likes.

\section{RESULTS AND DISCUSSION}

\subsection{Characteristic of Probiotic Biscuit Color}

Color is one of the factors that determine the quality and visually appear first and sometimes very decisive, so the color is an important organoleptic attribute in a food [13]. The result of comparison of waste of skin of bean sprouts flour with ganyong flour did not give a real different effect to the color of probiotic biscuit through panelist sensory. The results of statistical test of probiotic biscuit color can be seen in Table 1 .

Table 1. Effect of Variation Skin Waste of Bean Sprouts Flour with Ganyong Flour to Color of Probiotic Biscuits

\begin{tabular}{|l|c|}
\hline \multicolumn{1}{|c|}{ Treatment } & Average \\
\hline $\begin{array}{l}\text { P1 (TLKT } 20 \%: \text { TG } \\
\text { 60\% : TT 20\%) }\end{array}$ & $3.47 \mathrm{a}$ \\
\hline $\begin{array}{l}\text { P2 (TLKT } 30 \%: \text { TG } \\
50 \%: \text { TT } 20 \%)\end{array}$ & $3.67 \mathrm{a}$ \\
\hline $\begin{array}{l}\text { P3 (TLKT } 40 \%: \text { TG } \\
\text { 40\% : TT } 20 \%)\end{array}$ & $3.33 \mathrm{a}$ \\
\hline
\end{tabular}

Different letter means significant at 95\%

Based on Table 1, the average score on the color of probiotic biscuits that was not significantly different was not influenced by the difference in the ratio of waste of bean sprouts skin flour and ganyong flour. The color of the probiotic biscuits produced is between light to dark green. The dark green color is rather light made from one of the main ingredients of skin waste of bean sprouts that has a dark green color. The green 
color comes from the green pigment that is chlorophyll. Chlorophyll is a green pigment contained in chloroplasts. In high plants, chloroplasts are mainly present in the palisade parenchymal tissue and leaf sponge parenchyma. In chloroplasts, the main pigments of chlorophyll and carotenoids and xantophils are present in the thylakoid membrane [14].

Refer to [13], color is very visually determine a food accepted or not by the public or consumers. Foods that taste good, nutritious and well-textured will not necessarily be liked by the consumer if the food has an unsightly color or deviate from the color that should be. In addition, the color scores of probiotic biscuits are in the range of 3.33 - 3.67. These conditions indicate that the color of the biscuit belongs to a rather likes category by panelists.

\subsection{Characteristic of Probiotic Biscuit Aroma}

The smell of food much determines the delicacy of the food, therefore the aroma is one factor in the determination of quality [15]. The result of comparison of waste of bean sprout skin flour with ganyong flour did not give a real different effect to the aroma of probiotic biscuits through panelist sensory. The results of statistical tests of the aroma of probiotic biscuits can be seen in Table 2 .

Table 2. Effect of Variation Skin Waste of Bean Sprouts Flour with Ganyong Flour to Aroma of Probiotic Biscuits

\begin{tabular}{|l|c|}
\hline \multicolumn{1}{|c|}{ Treatment } & Average \\
\hline $\begin{array}{l}\text { P1 (TLKT 20\% : TG } \\
60 \%: \text { TT } 20 \%)\end{array}$ & $3.47 \mathrm{a}$ \\
\hline $\begin{array}{l}\text { P2 (TLKT } 30 \%: \text { TG } \\
50 \%: \text { TT } 20 \%)\end{array}$ & $3.40 \mathrm{a}$ \\
\hline $\begin{array}{l}\text { P3 (TLKT } 40 \%: \text { TG } \\
\text { 40\% : TT 20\%) }\end{array}$ & $3.53 \mathrm{a}$ \\
\hline \multicolumn{2}{|l|}{ Different letter means significant at 95\% }
\end{tabular}

Based on Table 2, the average score on the aroma of probiotic biscuits that was not significantly different was not influenced by the difference in the ratio of waste of bean sprout skin flour and ganyong flour. The smell of probiotic biscuits pro-duced is a distinctive aroma of bean sprouts.

The aromas that arise are caused when the roasting process of volatile compounds contained in the evaporated material [16]. The aroma of biscuits is also caused by the various components of the main ingredients in the dough such as flour waste of bean sprouts and ganyong flour. $[17,18]$ Developer materials in the manufacture of cookies serves as a aroma regulator. In addition, the scores of probiotic biscuits are in the range of $3.40-3.53$. The condition indicates that the aroma of probiotic biscuits belongs to a somewhat dislikes category by panelists.

\subsection{Characteristic of Probiotic Biscuit Flavor}

Flavor in food products especially probiotic biscuits is very important because it is one of the determinants of foodstuffs and quality indicators. Foods that have tasty and appealing taste will be favored by consumers. The result of comparison of flour waste of skin of bean sprouts with ganyong flour gave a real different effect to the taste of probiotic biscuit through panelist sensory. The results of statistical tests of the taste of probiotic biscuits can be seen in Table 3 .

Table 3. Effect of Variation Skin Waste of Bean Sprouts Flour with Ganyong Flour to Flavor of Probiotic Biscuits

\begin{tabular}{|l|c|}
\hline \multicolumn{1}{|c|}{ Treatment } & Average \\
\hline $\begin{array}{l}\text { P1 (TLKT } 20 \%: \text { TG } \\
60 \%: \text { TT } 20 \%)\end{array}$ & $2.47 \mathrm{a}$ \\
\hline $\begin{array}{l}\text { P2 (TLKT } 30 \%: \text { TG } \\
50 \%: \text { TT } 20 \%)\end{array}$ & $3.47 \mathrm{a}$ \\
\hline $\begin{array}{l}\text { P3 (TLKT } 40 \%: \text { TG } \\
40 \%: \text { TT } 20 \%)\end{array}$ & $2.93 \mathrm{ab}$ \\
\hline
\end{tabular}

Different letter means significant at 95\%

Based on Table 3, the average score on the color of probiotic biscuits that was not significantly different was not influenced by the difference in the ratio of waste of bean sprout skin flour and ganyong flour. This condition is in accordance with a statement from [14], that the texture and consistency of the ingredients will affect the flavor 
generated by the material. Changes in texture of the material can be generated because it affects the smell and taste. This greatly affects the rate of arousal stimulation of olfactory receptor cells from the panelist salivary glands.

The flavors produced by probiotic biscuits are bitter, salty, and slightly acidic. The bitter taste produced can be caused by the bitter taste of the bean sprouts waste, while the salty and sour taste can be caused by the effect of Na-metabisulphite immersion in the process of making the ganyong flour. $[19,16]$ The flavor created by food products can come from food itself is also derived from substances that are added from the outside during the process so that it can cause a sharp taste or vice versa be reduced. In addition, the taste scores of probiotic biscuits are in the range of $2.47-3.47$. These conditions indicate that the taste of probiotic biscuits belongs to somewhat dislikes category by panelists.

\subsection{Characteristic of Probiotic Biscuit Appearance}

The overall appearance is the consumer's assessment of a food product. The result of comparison of waste of bean sprout skin flour with ganyong flour did not give a real different effect to the overall appearance of probiotic biscuit through panelist sensory. The statistical results of the overall appearance of probiotic biscuits can be seen in Table 4.

Table 4. Effect of Variation Skin Waste of Bean Sprouts Flour with Ganyong Flour to Appearance of Probiotic Biscuits

\begin{tabular}{|c|c|}
\hline Treatment & Average \\
\hline P1 (TLKT 20\%:TG 60\% : TT 20\%) & $3.73 \mathrm{a}$ \\
\hline P2 (TLKT 30\%:TG 50\%: TT 20\%) & $3.87 \mathrm{a}$ \\
\hline P3 (TLKT 40\%:TG 40\% : TT 20\%) & $3.40 \mathrm{a}$ \\
\hline \multicolumn{2}{|l}{ Different letter means significant at 95\% } \\
\end{tabular}

According to Table 4, the average score on the overall appearance of the probiotic biscuit that was not significantly different was not influenced by the difference in the ratio of waste of bean sprout skin flour and ganyong flour. The overall appearance of the resulting biscuit is to have dark green color, bitter and sour aroma and taste, round shape is not comical, the surface is flat, slightly shaft, and crunchy. In addition, the overall appearance score of probiotic biscuits is in the range of $3.40-3.80$. These conditions indicate that the overall appearance of biscuits belongs to the rather favored category by panelists.

\subsection{Characteristic of Probiotic Biscuit Texture}

The result of comparison of flour waste of skin of bean sprout with ganyong flour did not give a real different effect to the texture of probiotic biscuit through panelist sensory. The statistical test results of probiotic biscuit texture can be seen in Table 5.

Table 5. Effect of Variation Skin Waste of Bean Sprouts Flour with Ganyong Flour to Texture of Probiotic Biscuits

\begin{tabular}{|l|c|}
\hline \multicolumn{1}{|c|}{ Treatment } & Average \\
\hline $\begin{array}{l}\text { P1 (TLKT } 20 \%: \text { TG } \\
60 \%: \text { TT } 20 \%)\end{array}$ & $3.80 \mathrm{a}$ \\
\hline $\begin{array}{l}\text { P2 (TLKT } 30 \%: \text { TG } \\
50 \%: \text { TT } 20 \%)\end{array}$ & $4.13 \mathrm{a}$ \\
\hline $\begin{array}{l}\text { P3 (TLKT } 40 \%: \text { TG } \\
40 \%: \text { TT } 20 \%)\end{array}$ & $3.87 \mathrm{a}$ \\
\hline
\end{tabular}

Different letter means significant at 95\%

Based on Table 5, the average score on the texture of probiotic biscuits that was not significantly different was not influenced by differences in the ratio of waste of bean sprout skin flour and ganyong flour. The texture of the resulting probiotic biscuits is crunchy.

The texture is determined by the hardness of the biscuit. Hardness in biscuit products is influenced by gluten-forming proteins, starch granules, and fatty content [20]. Differences in the composition of carbohydrates, proteins and fats between the bean sprouts waste flour and ganyong flour can also affect the difference in biscuit texture. The use of wheat flour on a probiotic biscuit also affects the texture of the biscuit, where the amount of flour is used slightly so that the composition of the gluten-forming 
protein is also small. The gluten plays a role in the determination of plasticity of food made from wheat [21]. In addition, the probiotic biscuit texture score is in the range of 3.80 4.13. These conditions indicate that the overall appearance of biscuits belongs to the rather favored category of panelists.

\subsection{Characteristic of Probiotic Biscuit After Taste}

After taste is a perverted flavor that is left after chewing or consuming a food product. The result of comparison of flour waste of bean sprout skin with ganyong flour did not give a real different effect to after taste of probiotic biscuit through sensori panelis. Results of statistical tests after taste of probiotic biscuits can be seen in Table 6 .

Table 6. Effect of Variation Skin Waste of Bean Sprouts Flour with Ganyong Flour to After Taste of Probiotic Biscuits

\begin{tabular}{|c|c|}
\hline Treatment & Average \\
\hline P1 (TLKT 20\%:TG 60\%:TT 20\%) & $2.47 \mathrm{a}$ \\
\hline P2 (TLKT 30\%:TG 50\%:TT 20\%) & $3.20 \mathrm{a}$ \\
\hline P3 (TLKT 40\%:TG 40\%:TT 20\%) & $2.87 \mathrm{a}$ \\
\hline
\end{tabular}

Different letter means significant at 95\%

Based on Table 6, the average score on the after taste of probiotic biscuits that was not significantly different was not influenced by the difference in the ratio of waste of bean sprout skin flour and ganyong flour. After taste of probiotic biscuits are bitter and sour sting. In addition, the after taste score of probiotic biscuits is in the range of $2.47-3.20$. These conditions indicate that the overall appearance of biscuits belongs to a somewhat dislikes category of panelists.

\section{CONCLUSSION}

Based on the results of research that has been done, it can be concluded that variation of skin taste of beans sprouts flour with ganyong flour give a significant effect on flavor, but give not a significant effect on color, aroma, appearance, texture, and after taste of probiotic biscuit.
Probiotic biscuit with variation formula P2 30\% skin waste of bean sprout flour : $50 \%$ ganyong flour $(\mathrm{w} / \mathrm{w})$ were selected as the best characteristic probiotic biscuits with perceived a bit like by the panelist.

\section{ACKNOWLEDGMENT}

The authors thank to Ms. Indira L. K. and Ms. Heni R. A. as lecturer in Dept. Foodindustrial Technology, Agroindustrial Faculty, Universitas Padjadjaran for providing financial and research support, to parents who give full support morally and to all friends who have taken time helping this research.

\section{REFERENCES}

[1] Rahayu, S. D. S. W. dan W. W. Ifafah. 2010. Survei Potensi Limbah Tauge di Kota Madya Bogor. Laporan Penelitian. Fakultas Peternakan. IPB. Bogor.

[2] Badan Pusat Statistika. 2017. Konsumsi Buah dan Sayur Susenas Maret 2016. Dalam Rangka Hari Gizi Nasional 2017. Tersedia di : http://gizi.depkes.go.id (accessed on June 18th 2018).

[3] Rukmana, R. 2000. Ganyong, Budidaya dan Pascapanen. Kanisius. Yogyakarta.

[4] Direktorat Gizi Departemen Kesehatan RI. 2000. Daftar Komposisi Bahan Makanan. Bhratara Karya Aksara. Jakarta.

[5] Purwaningsih, H., Irawati, Riefna. 2013. Karakteristik Fisiko Kimia Tepung Ganyong sebagai Pangan Alternatif Pengganti Beras. Balai Pengkajian Teknologi Pertanian (BPTP). Yogyakarta.

[6] Amaliah, N. 2002. Daya Terima dan Nilai Gizi Biskuit Terfortifikasi Zat Besi dengan Penambahan Tepung Ikan Selar (Calanx sp.). Skripsi. IPB. 
[7] Soeharsono, H. 2010. Probiotik. Widya Padjadjaran. Bandung.

[8] Senditya, Meirza, M. S. Hadi, T. Estiasih, E. Saparianti. 2014. Efek Probiotik dan Probiotik Simplisia Daun Cincau Hitam (Mesona palustris BI) Secara In Vivo: Kajian Pustaka. Jurnal Pangan dan Agroinudstri Vol. 2 No. 3 p.141-141. Teknologi Hasil Pertanian. FTP. Universitras Brawijaya. Malang.

[9] Sumanti, D. M., I., S., Setiasih, R., L., Balia dan Karuniawan. 2009. Karakteristik Kimia dan Fungsional Tepung Komposit (Bonggol Pisang, Ubi Jalar, Kedelai Hitam) serta Aplikasinya pada Biskuit Probiotik. Disertasi. Universitas Padjadjaran, Bandung.

[10]Slamet, A. 2010. Pengaruh Perlakuan Pendahuluan pada Umbi Ganyong terhadap SIfat Fisik dan Amilografi Tepung Ganyong yang dihasilkan. Jurnal Agrointek Vol 4 (2). Jurusan Teknologi Hasil Pertanian. Fakultras Agroindustri. UMB. Yogyakarta.

[11]Sumanti, D. M., M. Djali, dan I. Lanti. 2013. Rekayasa Sifat Fisikokimia Tepung Komposit Lokal (Bonggol Pisang, Ubi Jalar, Kedelai) dan Aplikasinyadalam Produk Pangan Fungsional untuk Menunjang Ketahanan Pangan di Jawa Barat. Laporan Kegiatan PNP 2012. FTIP. Unpad. Jatinangor.

[12]Soekarto, S. T. 1985. Penilaian Organoleptik (untuk Industri Pangan dan Hasil Pertanian). Bharata Karya Aksara. Jakarta.

[13]Winarno, F. G. 2004. Kimia Pangan dan Gizi. Gramedia. Jakarta.
[14]Sumaenda, L. 2011. Analisis Kandungan Klorofil Daun Mangga (Mangifera indica L.) pada Tingkat Perkembangan Daun yang Berbeda. Bioslogos 1 (1). Tersedia di : media.neliti.com (accessed on July 18th 2018).

[15]Asmaraningtyas, D. 2014. Kekerasan, Warna, dan Daya Terima Biskuit yang disubtitusi Tepung Labu Kuning. Naskah Publikasi. Program Studi Ilmu Gizi. Fakultas Ilmu Kesehatan. Universitas Muhammadiyah Surakarta.

[16] Mayasari, R. 2015. Kajian Karakterstik Biskuit yang dipengaruhi Perbandingan Tepung Ubi Jalar (Ipomea batatas L.) dan Tepung Kacang Merah (Phaseolus vulgaris L.). Artikel Ilmiah. Program Studi Teknologi Pangan. Fakultas Teknik. Universitas Pasundan. Bandung.

[17] Matz, S. A. dan Matz T. D. 1978. Cookie and Craker Technology. AVI Publishing. Co. Inc. Wetsport. Connecticut.

[18]Subandoro, R.H.,Basito \& Atmaka, W.2013.Pemanfaatan Tepung Millet Kuning dan Tepung Ubi Jalar Kuning sebagai Substitusi Tepung Terigu dalam Pembuatan Cookies terhadap Karakteristik Organoleptik.Jurnal Teknosains Pangan 2(4).68-74.

[19]deMan, J. M. 1997. Kimia Makanan. ITB. Bandung.

[20]Lewis. 1978. Physical Properties of Food and Food Processing System. Ellis Howood Ltd. England.

[21]APTINDO, 2012. Kelas Menengah Tumbuh, Konsumsi Terigu Melejit. Available at : http://www.aptindo.or.id. (accessed on July 18th 2018). 